\title{
National Obsessions and Identities in Football Match Reports
}

\author{
by Liz Crolley, David Hand and Ralf Jeutter \\ Manchester Metropolitan University
}

Football match reports are one of the mainstays of the sports pages of both "tabloids" and "quality" newspapers across Europe. The present study constitutes the first attempts to analyse match reports in French, German and Spanish "quality" dailies with a view to extracting themes which reflect national obsessions and identities. Some of these themes may be common to all three countries with, perhaps, some differences of perspective, while others may well be country-specific. The data were collected over a five month period, namely July - November 1995. It is envisaged that this study will form part of a larger piece of research investigating styles of football match reports.

The newspapers analysed were Le Monde and Libération in France, Süddeustche Zeitung in Germany and El País in Spain. Le Monde, founded in 1944, is a quality newspaper read generally by an educated élite, politically to the left of centre while Libération is a slightly more popular daily (although quite unlike the tabloid style of English popular press) born of the 1968 ideology of Resistance. El País is a tabloidsized quality daily Spanish newpaper, politically, traditionally to the left of centre and generally considered to bias Spain's PSOE socialist government which held power from 1982 - 96. The German newspaper examined is in political outlook a liberal to left-wing daily, comparable in England to The Guardian. It is, therefore, no surprise that the match reports are rife with political vocabulary originating in the 1960s. The tone of the reportage is consistently ironic and detached. It seems that in Germany football cannot yet be made part of a serious intellectual discourse. From the space which is given to match reports, it is clear that football is an important issue but nevertheless the writing is in the as if mode - as if football is not important - although it can safely be assumed that neither for the writers nor for the readers is football the least important matter in their life. 
Blain and O'Donnell (1997) have noted the unique nature of the tabloid press in Britain, and especially in England, and suggest that the "quality" dailies of continental Europe fall into a different category. However, is this division between Europe and the UK so clear-cut? Is it not possible that football in France, Germany and Spain is presented as being an extension of society? By analysing how national obsessions and identities are reflected in the metaphors and imagery used in French, German and Spanish football match reports, we might discover that football is more than self-referent and more than a sign of society. The way in which football reports are constructed in the newspapers under consideration tells us something about society and this is true in all three countries studied here. Could it be, then, that the real differences between the UK and continental Europe regarding the relationship between football and society are rather ones of style and degree?

It is this very relationship between football and society which becomes clear when analysing the use of imagery and metaphor in match reports. In the broadest sense, imagery may be seen as a linguistic device which suggests mental pictures through vivid descriptions while a metaphor, itself an image, implies an analogy or close comparison between two objects that are not normally treated as if they had anything in common. Obvious, clichéd metaphors have been largely avoided in the analysis and for the purposes of this research more imaginative metaphors and imagery are examined. It is important to emphasise that it is the researchers' own reading and interpretation of reports that is outlined. The readings are, therefore, unashamedly subjective and open to further comment and interpretation. It is difficult to make clear links between football writing and fandom, but there appear to be several occasions where cultural or political references apparent in the data are reflected in the behaviour of football fans in the countries concerned. These connections are highlighted later on.

Taking a thematic approach, topics such as war, money/business and religion are to be found in football match reports in all countries, although interestingly they can 
be employed in a slightly different way in each and thus reflect the way in which these themes are perceived in each country. The countries' individual national identities or obsessions are also mirrored in the choice and variety of images such as health (in France), political vocabulary of the 1960s (in Germany) and bullfighting (in Spain).

Among the most central themes in many match reports is that of war. Images of war can be as clichéd as the midfield 'pocket battleship' but not as extreme as some of the reports which appeared in the English tabloids during Euro '96, typified by the Daily Mirror's headline 'Achtung! Surrender' (24 June 1996) whose obvious and vivid metaphor received widespread criticism. One of France's national obsessions is its military past and France has had, of course, a long history of military victories and defeats, perhaps the longest of all European nations dating, as it does, back to the ninth century. The imagery of warfare in football match reports is probably most apparent when French teams play foreign ones either in club or international competitions. The French are still haunted, for instance, by their defeat in May 1940 at the hands of the Germans, the obsession being with the strength of the German Blitzkrieg, its efficiency, and, above all, its sheer speed, characteristics which might be considered part of a wider German identity as perceived by the French. Interestingly, then, when Bordeaux played the German outfit Karlsruhe on their way to the 1996 UEFA Cup Final, the military imagery of the match report centred on the Germans' qualities in occupying key areas of the battlefield and 'the frightening speed' of their attacks (Libération 9.8.1995).

Similarly, the last time Great Britain and France were at war (with each other, that is) was Waterloo in 1815 marking the end of the Napoleonic wars which were, of course, wars still fought with canon and muskets. This very imagery of early nineteenth century warfare crept into the match report of the 1995 UEFA Cup match between the future double winners of that season, Auxerre, and England's Nottingham Forest. This match was described by the journalist as a real battle in which one could 'smell the powder' and see 'the canon fire' (Libération 18.10.1995). 
Again, when the French national team beat Rumania in a Euro 96 qualifier away in Bucarest, the line-up was described in the match report as 'closed ranks' resisting the Rumanian attacks led by their star 'swordsman' Hagi in a successful attempt to defend their 'fort.' At the very end of the game, leading 1-2, victory was assured, we note, when 'the French guard had no need to retreat' but, on the contrary, advanced to score a third goal (Libération 12.10.1995).

As a final example, we may quote the remarkably subtle and finely tuned military imagery used to describe the encounter between France and Poland in another Euro 96 qualifying match. In a military sense, the Poles are remembered historically in France as being great cavalrymen in the early nineteeth century. This imagery from the French collective unconscious resurfaced in the report of the match in question in which there are references to 'the attacks of the light horsemen' and 'the sabre strikes' of the Polish forwards (Libération 17.8.1995).

In common with the French (and English) match reports, military imagery has a strong presence in Spanish football writing. Unlike in France, the images and metaphors are frequently less specific and more general in nature, although they do have some characteristics particular to Spain. Many are almost clichés in nature: 'Oviedo used all their ammunition' (El País 27.11.1995); 'Atlético de Madrid have the spirit of a warrior' (E्l País 2.10.1995); 'Sevilla bombed the area' (EI País 27.11.1995); 'Real Sociedad lacked the imagination necessary to kill off a wounded side' (EI País 2.10.1995).

It is indeed startling to note the number of references to 'reconquests' (seventeen in this period alone) compared to the relatively few references to 'conquests' (just three). Many writers refer to a fight-back as a 'reconquest'. The reconquest of the territory of Spain by the Christians from the Moors in the fifteenth century is, of course, one of the most important aspects of Spain's history and the unity of Spain as an administrative and political entity dates back to this period. It is not surprising, therefore, in a forum which seems to reflect national identities to encounter images and metaphors relating to this 
period: 'The Atlético reconquest began ... and de la Peña was injured' (El País 27.11.1995).

As well as these rather obvious images and metaphors, others can be imaginative and highly developed. After a dirty match in which six players were booked in midfield, one writer reported that, 'Sevilla and Atlético de Madrid decided to fight in unoccupied territory [i.e. in midfield] and the match ended up without a victor. The result was a battle with many injured [booked] but surprisingly no fatalities [sendings-off].' (E्] País 2.10.1995) Another journalist continues the elaborate metaphor throughout the report: 'A brave team turned up. Betis took risks but Tenerife escaped barechested [with little with which to defend themselves]. They didn't notice the fact that Alfonso was secretly stalking them. He took on Llorente with all his ammunition and then all that was needed was a cross towards the unprotected stakes... Felipe managed to clear to a trouble-free zone and from there began to organise the ranks... Pizzi meanwhile loaded his arms and released the gunpowder shortly afterwards.' (El País 6.11.1995)

The notion of an army needing direction and leadership is a recurring theme in Spanish match reports. In this respect the Spanish football reports are unique in the collection. Unlike in France, Germany and England where football teams are more likely to be compared to an army when they are organised and disciplined, in Spain teams are consistently referred to in militaristic terms when they are disorganised or lack leadership. This might appear surprising given the common association between army and strict organisation/discipline, but it serves to provide an insight into the Spanish perception of their armed forces, $60 \%$ of which are youths (usually reluctantly) carrying out their military service. It reflects too the legacy of the Spanish Civil War in which both sides, the defeated Republicans and the victorious Nationalists, consisted of volunteers with little or no experience. Anyone who has seen the film Land and Freedom directed by Ken Roach or has read George Orwell's Homage to Catalonia can imagine how poorly organised these troops were. The following passage serves to illustrate how 
these perceptions of 'an army' remain today. In the report of a match between Mérida and Real Sociedad, 'The manager opted to simulate a Revolution..., he made many changes and ended up with a disorganised army with no intelligence service and with too many troops. The battle was a formality [at this point the metaphor switches], a collision between two steam-trains chugging along a track [it then switches back to the war imagery]. In two aerial attacks Mérida conquered Real Sociedad.' (El País 16.10.1995) So unlike the militaristic characteristics of football writing in France, Spain's national obsession with war is more specifically related (athough never directly referred to as such) to the Spanish Civil War.

To move on to the second theme, politics, specific references are very common in German match reports. Political metaphors relevant to the 1960 s noted in the sample include reference to the 'long march' (Süddeustche Zeitung 27.11.1995), clearly a reference to the long march of the Communist Revolution in China, but also an allusion to the political strategy of those who became disillusioned with direct political action and who did not want to go the way of the terrorists. The football world in Germany can be divided into left-wing and right-wing. The Hamburg team St. Pauli, for example, is perceived to be a left-wing team. Its left-wing/anarchist image has been adopted by its fans and this is reflected both in fans' projects and in the fanzines of St. Pauli fans. The St. Pauli manager himself is on record as saying, 'I don't think German society offers a very fertile soil for a revolution at the moment.' (Süddeustche Zeitung 27.11.1995) On the other hand, Hansa Rostsock (former GDR) is seen to have strong right-wing support.

A difference can be made between the ideological fundamentalists and the pragmatists like in the debates within the Green Party. A crisis meeting of the Bayern Munich presidial committee, for instance, is compared to a 1960 s commune (Süddeustche Zeitung 27.11.1995) whereby the main points of discussion are who will do the washing up, who the cleaning, etc. The range of tactics employed in the Bundesliga is conveyed using a famous formula, 'The new confusion' (Süddeustche 
Zeitung 20.11.1995), coined by the most eminent post-Adorno sociologist and philosopher Jürgen Habermast, who applied this catch-phrase to the confusing range of ideologies available in the post modern philosophical shops. One journalist detects 'cultural pessimism' (Süddeustche Zeitung 27.11.1995) in the statement of one of the managers, a turn of phrase which invokes an intellectual debate dating back to early nineteenth century Germany and which became virulent again in the 1960s. Those who were accused of 'cultural pessimism' were those politically suspect people who did not share the revolutionary optimism of so many of the students' generation.

The question has to be posed why German football match reports are so steeped in this kind of vocabulary, a marriage which is slightly mismatched it would seem at first glance. In the more cynical 1980s and less ideological 90s, this sort of serious political discourse has lost a lot of its credibility. If at all, it can only be used tongue in cheek or with distancing devices like irony and since intellectual German writing cannot bring itself to write seriously about football, the employment of this sort of vocabulary is not a bad way of showing a little haughtiness, while at the same time allowing journalists to invest football with the ingredients of (although only mock) political discourse, reminiscent of the 'transcontextualisation' of football and political terminology found in Italy (Duke and Crolley 1996). Again, the political discourse is sometimes transferred into the behaviour and symbolism within football fan culture, a culture in which political allegiances and identification with a football club can coexist and one cannot always be considered to the exclusion of the other.

From the political vocabulary of the 1960s in Germany, we come right up to date with a look at the vocabulary of the 1990s in France. The Thatcher revolution successfully crossed the English Channel in the mid 1980s with the result that, in France now as in many other countries, whereas business used to be a part of life, life - and football with it - is now a business. It comes as no surprise, then, to read French football match reports in which the activities of the players on the pitch are described using 
commercial language and discourse. Possession of the ball, for instance, can be seen as 'a monopoly' (Libération 30.8.1995). Similarly, one team quickly becomes 'the boss on the park' (Libération 28.10.1995) (although this is such a widely used phrase in English and, probably, in French as to qualify as a cliché). A whole team in French match reports is often described as 'enterprising' (Le Monde 4.11.1995) or 'workmanlike' (idem). The players involved may be 'trainees' (Le Monde 2.11.1995) or, on the other hand, 'a consortium' (Le Monde 20.10.1995) while a key element of business transactions, the contract, is a constantly recurring item in the lexis of French football match reports: to quote a single example, when France beat Israel to clinch a place in the finals of Euro 96, the report stated that 'the contract [had been] duly fulfilled' (Le Monde 17.11.1995).

Again, failure on the pitch is often conveyed in the French press by the vocabulary of failure in business as demonstrated by the example of France's 1-1 'defeat' against Poland in a Euro 96 qualifier being described as 'bankruptcy' (Le Monde 18.8.1995). Finally, a French team doing well in Europe, Lens (but ultimately not quite as well as Paris Saint Germain who went on to win the 1996 Cup Winners' Cup) was said in one match report to be 'pursuing its European career' (Le Monde 3.11.1995). It is possible that the practice of leaving business cards by some fans, such as Paris SaintGermain, in the late 1980s (Broussard 1990: 171) could be interpreted as an extension of this business theme into football fandom, although it is more probable that this custom was an imitation of English football culture. In time, it will be interesting to see whether or not the number of references to the businessworld increases given the continued rise in commercialism of football in France and indeed across Europe.

As with France, when we talk about national obsessions in Germany, surely one of the main topics will always be matters relating to money, because Germany shaped its post-war identity on the basis of economic strength. On the other hand, the Germans do have a very strong idealistic streak in their character, as displayed in their history and 
cultural and philosophical endeavours. Immediately after 1945, football became an area where this brand of idealism could find expression. All those values which were corrupted under Nazi rule could now, albeit only temporarily, find a home in the football arena. Unselfishness, cooperation, service to the nation, were then concepts very much in vogue, conveniently disguising the opposite impulses in German society and also underplaying the political implications of such 'disinterested love' for football. The endemic employment of metaphors stemming from the world of business suggests great disappointment and consequently a cynical approach to the game.

One of the most repeated topics in the football match reports of the Süddeutsche Zeitung is the way individual footballers use their skills purely for self-marketing purposes. It is no surprise, then, that so many metaphors can be found relating to the business world. The football club is a 'firm', the footballers the 'employees' or the 'salaried employees' and the manager the 'head of department' or a 'leading employee'. A lost away game is a 'sad company outing'; a footballer can be a 'kicking entrepreneur'; 'damages' are part of 'the salary'; a manager or player can suffer from what the Germans call Betriebsblindheit, being blind to the shortcomings of one's own company. A football match is a 'Saturday shift' which takes place on a 'working day'. Success in sport is a 'lubricant for successful business transactions'. The audience is the 'customer', either angry or happy, depending on the quality of the match. One journalist talks about the 'green economic miracle lawns', referring back to the 50s/early 60s when Germany's rise to economic superstardom started. The whole of the football experience is summed up in the words 'football adventure park' and a player, when injured or sick, has to hand in what the Germans so beautifully call a 'Arbeitsunfahigkeitsbescheinigung', a sick-note, like any other employee in the world of business. (Süddeustche Zeitung 13.11.1995; $25.9 .1995 ; 6.11 .1995)$

In Spain too, the football world is described in terms of the world of work. Football clubs have become businesses (literally as well as metaphorically - in 1992 all Spain's 
professional football clubs became Sociedades Anónimas, or public limited companies). Hence, the labelling of a club as a 'company' and its supporters as 'shareholders' is no longer, strictly speaking, solely metaphorical. Nevertheless, in the last few years in particular there has been a rise in the use of metaphors which describe footballers as 'workers', and refer to their 'earning a living'. No longer are they idols who play football to represent the people. They do it for money and are described in these terms. However, the Spanish case differs from the French and German in its specificity. When Spanish footballers circulate in the world of work they are civil servants ('funcionarios). It is when they are performing without passion that these images are portrayed. This theme is intensely Spanish. Spanish society is riddled with bureaucracy and the legacy lingers of the image of the demotivated civil servant whose position, secure for life, was obtained as a reward for services to the Franco Regime.

Teams or players who are accused of going through the motions, playing without passion, for the money, are, then, often compared to 'funcionarios'. 'Spain formalised their documentation to go to England [for the 1996 European Championships]. It was a task performed without passion, carried out in a civil servant-like style which was, of course, poor because of absenteeism [another accusation customarily directed at civil servants relevant here as players were being accused of preferring to play for their club and pulling out of the national team].' (22.10.1996) On a more personal level, individual players are accused: 'Julén Guerrero passes the ball with the deference of a post office worker [a civil servant in Spain]: he wraps the parcel, ties it, seals it and sends it with the vacant expression of a bureaucrat.' (El País 2.11.1995)

Next, an example of a field of metaphor specific to one country observed in the data is that of the cult of the leader, or even messianic vocabulary which, for obvious reasons one might think, is either very much in use or totally absent in Germany's football reportage. The Germans, it seems, cannot get rid of their obsession with leader figures. German footballers are not just geniuses on the field, role models for youngsters 
or cultural icons, they are equipped with more power than that: They are called 'the Emperor' (Kaiser Franz), and the leading literary critic 'the Pope'. The Süddeutsche Zeitung follows this pattern but, as always, ironically. Another important field of metaphors is, therefore, the messianic one, where the cult of the leader merges with religious under- or even overtones. About Matthäus, for instance, one journalist writes that 'media disciples gathered in feverish expectation in order to give birth to the new Messiah out of their sweaty, steaming midst.' (Süddeustche Zeitung 20.11.1995) He is, then, seen as the 'redeemer and Saviour'. Other less religiously-imbued metaphors are linked with the leader figure, be it that a football team is compared to an 'orchestra without a conductor' or that there are no 'chiefs around, only Indians' (Süddeustche Zeitung 25.9.1995). Finally, another journalist reminds the readers that 'one needs a pilot to fly a plane - flight attendants alone are not enough.' (Süddeustche Zeitung 25.9.1995)

Of course, it is neither unusual nor imaginative for match reports to contain references to idolatry; players are 'idolised' or 'worshipped' everywhere. What is interesting is the way in which it is exploited in each country. The importance of religious metaphor is by no means unique to any one country but it seems to have a particularly heavy presence in Spain, a traditionally Catholic country. Importantly, it is not just religious metaphor, but more specifically Catholic imagery that is portrayed (via reference, for example, to candles, saints, purgatory). Liverpool striker Robbie Fowler's nickname of 'God' found a parallel when Bebeto of Deportivo La Coruña scored five goals in one game against Albacete: 'Five goals in one game sanctify a player for a long time.' (El País 2.10.1995)

One or two examples will suffice to illustrate how religious imagery and metaphor go beyond the cliché in Spanish match reports. After Espanyol failed to score in four consecutive home games, the writer takes the religious theme to its ultimate conclusion. 'The older fans maintained the blind faith of the enlightened ... the crowd unafraid, in communion with their team. Then the goal arrived, and with it ecstacy [the state of the 
soul when in mystical communion with God]' (El País 2.10.1995). Mixing religious and literary metaphors, 'From his pulpit Cruyff watched a sketch from his latest great masterpiece.' (El País 6.11.1995)

Significantly in Spanish football match reports, not all religious metaphors conjure positive images. 'The eighteenth league fixture saw Atlético de Madrid return to the top of the table and two innocent victims sent to purgatory.' (El País 27.11.1995) It is important to note that this fixture took place in November, hence the two teams concerned were only relegated to purgatory and not to hell - there is still time for them to get out after they have suffered for a while!

Again, religious metaphors are used to depict a team in difficulty: 'Sevilla's mission was to run and run ... with their cross on their back ... but they played flowery football. They lit a candle for Unzúe [Sevilla's goalkeeper] who kept it burning.' (El País 9.16.1995) The image of the candle burning, a tradition of the Catholic church, is an unexpectedly frequent one in football match reports in Spain. Such heavy reliance on religious imagery serves to perpetuate the national stereotype of Spain as a strongly Catholic country.

Turning to France, one of the big issues which is reflected in the match reports is that of health care. France, as a nation, spends twice as much of its GDP on health care than Great Britain - a country with a similar population and economy - and the average French household spends seven times as much of its disposable income on health care than the average British one (Tableaux de l'économie française, INSEE, 1992). The importance of health and social security to the French people was also underlined for all to see when they took to the streets in their hundreds of thousands in November and December 1995 to protest against proposed government reforms to the system.

According to our theory of national obsessions translating into journalists' reports on the national game, there are many examples of health and body imagery at work in the French reports studied. Teams not performing well, for instance, are often described 
using the word 'fébrile', that is, 'nervous' or 'feverish' (Libération 16.10.11995). Similarly, the act of key players leaving a club leading to a downturn in performance on the field is described in one report as 'a haemorrhage' (Le Monde 2.11.1995): the outpouring of vital body fluid. Again, Nantes were French champions in 1995 but they made a bad start to the 1995-96 season which led to the team being described (retrospectively) in one report as 'apparently dead, deprived of its vital organs following the departures of Christian Karembeu and Patrice Loko,' two key French internationals (Le Monde 24.11.1995). When their performances improved, though, Nantes were portrayed as a team which had 'finished its convalescence and been cured' (Le Monde 20.10.1995). Conversely, a team whose poor performance had ultimately cost them their place in the first division, Guegnon, was often portrayed as 'sick' (Libération 6.11.1995) while a team with absolutely no hope at all of survival in the top flight who will, to spare their blushes, remain anonymous, was described as just plain 'dead' (Le Monde 24.11.1995), an absence of success on the field being conveyed in terms of a total absence of good health.

Continuing with the themes common in France, the French awareness of their country being a nation of artistic expression, music and literature is probably just as strong today as it has been through the centuries. If football is truly to be seen in France as a sign of society or even as an extension of society (Blain and O'Donnell 1997), then the vocabulary used in match reports will surely reflect this particular national obsession. To take literature as the first example, on numerous occasions images of and references to literature are employed. Goalscorers are often referred to as 'authors' as was the case with Bancarel ('auteur des deux buts'), the Bordeaux striker whose two goals knocked the Macedonians Skopje out of the UEFA Cup, while their teammates at the other end of the pitch, the goalkeepers, frequently become 'authors of great saves' as did, in the same report, Bordeaux's Huard against Volgograd (Libération 1.11.1995). Similarly, an entire team's efforts, good or bad, may be conveyed in literary terms as the example of 
Paris Saint Germain's disappointing showing in the league against En Avant de Guingamp demonstrates: their futile attempts to score were 'an anthology of missed opportunities' (Le Monde 28.7.1995).

A slightly different mechanism is at work in those match reports employing literary and artistic references rather than metaphors to describe activities on the field of play which, of course, raises interesting questions concerning the nature of the readership of such reports. A large part of the readership of Le Monde, for instance, is drawn from the teaching profession and student body which contrasts sharply with the perceived readership of some of the English tabloids. Two examples of references appealing to the educated elite in France will suffice. First, the national team's coach, Aimé Jacquet, once had his attempts to control his players' performances compared with Mary Shelley's best-know literary character via the following simile: 'Like Doctor Frankenstein and his creation, the coach knows he is not in total control of the machine he has worked so hard to build' (Le Monde 17.11.1995). The other example refers not to nineteeth century English literature but to nineteenth century French art: The Nantes players who held on so desperately to earn a 2-2 away draw in the Champions' League against Panathanaikos of Greece were described as heroic sailors, cast adrift in terrible circumstances, whose team spirit saw them through to survival just like 'les rescapés de la Méduse' (Le Monde 24.11.1995), the survivors of the shipwrecked vessel, the Medusa, who lived on a makeshift raft for weeks before being rescued and whose torment was immortalised in Géricault's 1824 painting The Raft of the Medusa now on display in the Louvre.

There are also themes specific to Spain which reflect interests, identity or obsessions; indeed some of these help to create or at least perpetuate the national stereotype. Teams playing in a lethargic manner are customarily accused of having a 'siesta'. The atmosphere in grounds too during hot weather is described as siesta time. 'Too hot, too sunny. It was a good siesta. Sevilla and Atlético de Madrid made a toast to 
the sun during the second half. In fact, there was no bull.' (El País 9.10.1995)

This last example makes reference to that other symbol of Spain, bullfighting. Borrowing of metaphors and imagery is frequent and invariably in the direction from bullfighting to football. An article in El País (23.6.1988) made the point that there are few metaphors taken in the opposite direction. The match is commonly referred to as '/a corrida' ('the bullfight') and in the above example where the players were so lethargic in the sun, 'there was no bull', that is, there was no match at all. A player who scores the winning goal is the 'matador' (the one who eventually kills the bull). The one producing an outstanding performance might be called a 'torero' ('a bullfighter'). This metaphor is reflected in the behaviour of football fans in Spain. It is not unusual for fans in a football ground to chant 'torero' to a player who has just demonstrated exceptional skills as they would to a bullfighter carrying off a particularly impressive move. Similarly, they might wave white handkerchiefs as an expression of deep emotion.

Other images and metaphors reflect the identities of the regions or nations that make up the politico-administrative unit of Spain. León Solís (1996) examined the ways in which several Spanish newspapers reported on their national team in the 1994 World Cup Finals. He illustrates how football is reported as 'an allegory of centre-periphery tensions and the team manager, the players and even the national anthem can often become metaphors for social, political and cultural cleavage.' Unsurprisingly, different patterns emerged within the coverage of each newspaper according to their political leanings. El País, the daily chosen for the purposes of this analysis, displayed what León Solís refers to as 'discurso diferencial', that is, a style of discourse that highlights the differences between nations/regions within the Spanish politico-administrative territory rather than the unitary or disjunctive (separatist) styles of discourse reflected in other newspapers (namely $\underline{\mathrm{ABC}}$ representing the former and Deia/Avui, Basque and Catalan dailies respectively representing the latter).

The images and metaphors conjured up in El País follow in the vein of León 
Solís's study in that they tend to reflect the regional/national stereotypes. Catalans are traditionally considered to be a hard-working population. FC Barcelona is a 'machine' which keeps going. Sevilla are described in terms of flowers - they play 'flowery football'. The stereotype of Andalucía, of which Sevilla is the capital, is one of flowers, colour and vibrance. It is no surprise, therefore, that their team is described with such metaphors. Football is thus reported in terms which reflect it as being an extension of society.

To conclude, we have seen that the imagery and metaphors used in our sample of French, German and Spanish football match reports are diverse, inventive and imaginative. Some of the themes evoked by them are common to all three of the countries concerned (war, business) but, perhaps, with differences of tone or referent while others are clearly country-specific (health in France, Messianism in Germany, geopolitics in Spain). In all cases, though, we contend that our initial findings suggest that football may, in mainland Europe, be more than simply a sign of society; football is reflected by the French, German and Spanish match reports studied as an extension of society in that so many of the images and metaphors used to describe it derive from French, German and Spanish constructions of collective identity. Clearly, the vocabulary and style (not to mention the readers) of our continental match reports cannot be said to be comparable to those employed by British tabloids reporting on football. However, we would stress that this difference between British tabloids, on the one hand, and French, German and Spanish quality dailies on the other is primarily one of style and, perhaps, degree but not necessarily one of typology in terms of the relationship between football and society as mediated by the press. In short, when we read a football match report in Le Monde, Libération, Süddeutsche Zietung, or El País, we are highly likely to encounter imaginative and adventurous (re)constructions of French, German and Spanish obsessions which, themselves, are rooted in French, German or Spanish perceptions of their own collective national identity. 


\section{References.}

Blain, N. and O'Donnell, H. (forthcoming) 'Living without the Sun: European Sports Journalism and its Readers', in M. Roche (ed.) Sport, Popular Culture and Identity, Aachen: Meyer and Meyer.

Broussard, P. (1990) Génération Supporter, Paris: Laffont.

Duke, V. and Crolley, L. (1996) Football, Nationality and the State, London: Addison Wesley Longman.

INSEE (1992), Tableaux de l'économie française, Paris: INSEE.

León Solís, F. 'El Juego de las nacionalidades', in International Journal of Iberian Studies, (1996) Vol. 9, No. 1, pp.28-45. 